\title{
CLINICAL STUDIES WITH THE AID OF RADIOACTIVE PHOS- PHORUS. I. THE ABSORPTION AND DISTRIBUTION OF RADIO-PHOSPHORUS IN THE BLOOD AND ITS EXCRETION BY NORMAL INDIVIDUALS AND PATIENTS WITH LEUKEMIA ${ }^{1}$
}

\author{
By L. A. ERF 2 AND JOHN H. LAWRENCE \\ (From the Crocker Radiation Laboratory and the Department of Medicine, University of \\ California)
}

(Received for publication April 9, 1941)

The purpose of this paper is $(a)$ to indicate the amount of radio-phosphorus $\left(\mathrm{P}^{32}\right)$ retained by various fractions of the blood of 4 normal individuals, 12 patients with myeloid, and 15 with lymphoid leukemia, and the variations in retention following the administration of radio-phosphorus when given orally and/or intravenously and when accompanied by varying amounts of non-radioactive phosphorus $\left(\mathrm{P}^{31}\right) ;(b)$ to indicate the distribution of $\mathrm{P}^{32}$ in the bone marrow and in various fractions of white blood cells; and $(c)$ to indicate the amount of radio-phosphorus excreted in urine and feces in these cases.

\section{MATERIALS AND METHODS}

The radioactive phosphorus was produced by the Berkeley cyclotron (1). The 4 normal individuals were robust, ambulatory workmen with recently healed fractures, all of whom had received the same type and quantity of food over a period of from 1 to 8 weeks, and each of whom had a single regular bowel movement daily during the same period previous to the administration of $\mathrm{P}^{39}$. It was impossible to control the diets or the time of excretion of the patients, all of whom were ambulatory. The blood withdrawn from veins was heparinized, cooled and centrifuged exactly 20 minutes at 1450 times gravity to insure constant volume. The buffy coat was aspirated, suspended in equal amounts of heparinized Ringer's solution and centrifuged exactly 20 minutes at 1450 times gravity. The plasma was then removed from the original tube and finally the red blood cells were extracted. Bone marrow obtained by sternal aspiration was heparinized and centrifuged, as described previously. In some instances, the nuclei were separated from the cytoplasm of the peripheral white blood cells by violent agitation for 20 minutes in cold 5 per cent citric acid (2). The phospholipids were extracted from the white blood cells by the use of ether, alcohol and reflux condensers, and the acid-soluble substances by use of ice-cold 5 per cent trichloracetic acid, thereby leaving

1 These investigations have been aided by a grant from the John and Mary R. Markle Foundation.

2 Wm. R. Kenan, Jr., Fellow. the nucleoprotein-like substances as residue (3). The assays of radioactivity were made by use of an electrometer.

\section{RESULTS}

The average percentages of the dose of administered $\mathrm{P}^{32}$ retained per $100 \mathrm{cc}$. of red blood cells, white blood cells and plasma of the normal individuals and of the patients are listed in Table I and illustrated in Figure $1 .^{3}$ The amounts and the method of administration of $\mathrm{P}^{32}$, the number of cases studied, and the intervals in time are also noted. No attempts were made to correct for variations in the metabolic rate, blood volume, kidney and hepatic functions, diet, age, weight, etc. of the cases studied. In computing the averages (Table I), the determinations obtained from both acute and chronic cases of leukemia were used. The acute cases are indicated.

(a) Retention of $P^{32}$ in whole blood. It can be observed that more $\mathrm{P}^{32}$ was retained, during

${ }^{3}$ All determinations in figures and tables were corrected for decay of radio-phosphorus (the half-life of which is 14.3 days) to date of administration. 1 microcurie $(\mu c)$ or $1 / 1000$ millicurie $(\mathrm{Mc})$ is equal to 37,000 beta particles per second.

It must also be pointed out that all the doses of $\mathrm{P}^{32}$ administered to the patients discussed in this paper were "therapeutic" and not "tracer" in nature, for even the smallest dose (540 microcuries) administered caused a decrease in the white blood cell levels of the patient. Therefore, the values obtained in the various metabolic studies must be considered as having been "conditioned" by the biological effects of the beta radiation emitted by the $\mathrm{P}^{2}$ and the information about cellular metabolism, which was obtained incidental to therapeutic attempts, must be interpreted with reservation and caution.

Although the average doses of radio-phosphorus administered orally to the various groups (normal, myeloid and lymphoid) are not similar, those administered intravenously are comparable (Table I). 


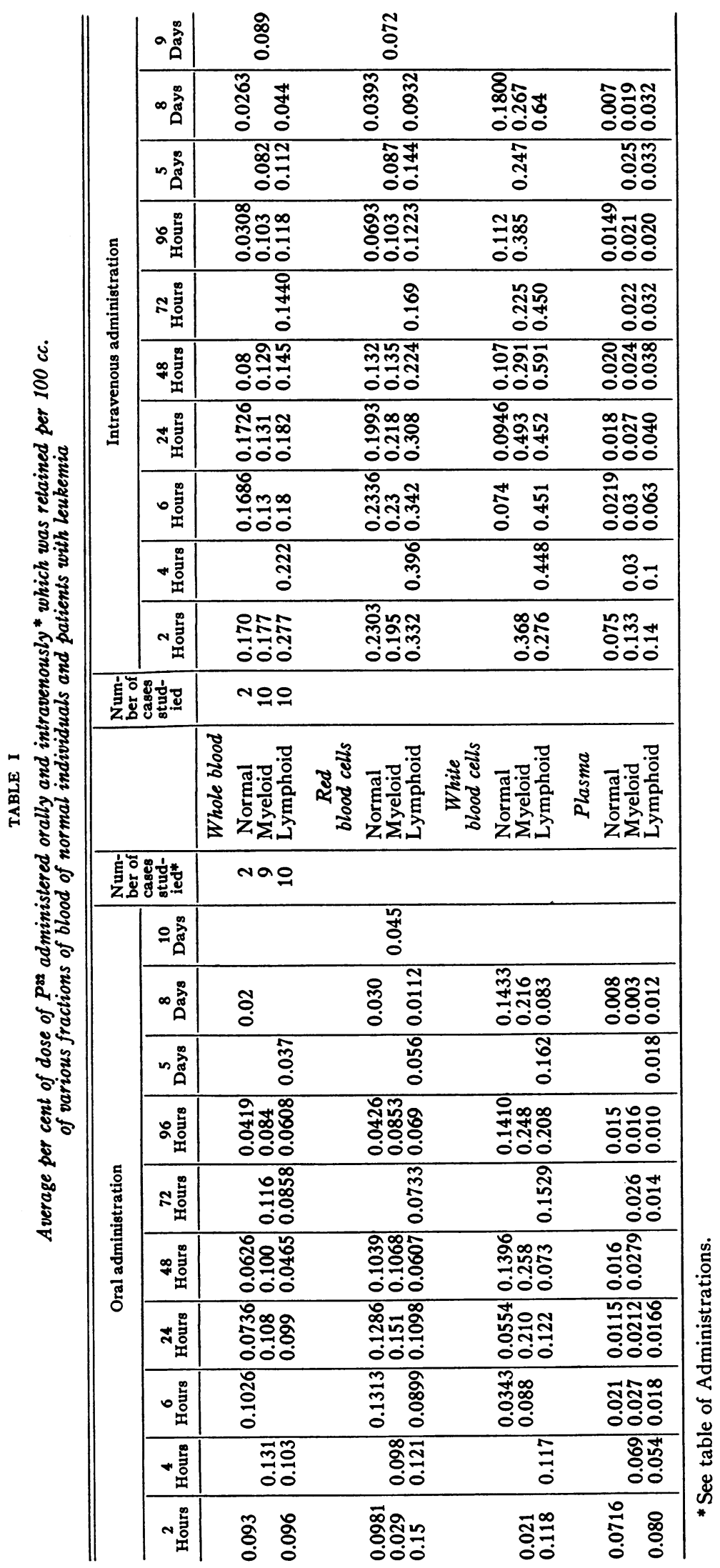


* Administrations †

\begin{tabular}{|c|c|c|c|c|c|c|}
\hline \multicolumn{3}{|c|}{ Oral } & & \multicolumn{3}{|c|}{ Intravenous } \\
\hline $\begin{array}{l}\text { Mgm. of } \\
\mathrm{Na}_{2} \mathrm{PO}\end{array}$ & $\begin{array}{l}\text { Microcuries } \\
\text { of } \mathbf{P s z}\end{array}$ & Cases & & Cases & $\begin{array}{l}\text { Microcuries } \\
\text { of } \mathbf{P}^{23}\end{array}$ & $\begin{array}{l}\text { Mgm. of } \\
\mathrm{Na}_{2} \mathrm{PO}\end{array}$ \\
\hline $\begin{array}{l}600 \\
600\end{array}$ & $\begin{array}{cc}1500 & \text { Average } \\
1500 & \\
& 1500\end{array}$ & $\begin{array}{l}1 \\
2\end{array}$ & Normal & $\begin{array}{l}1 \\
2\end{array}$ & \begin{tabular}{ll}
1500 & Average \\
1500 & \\
\cline { 1 - 1 } & 1500
\end{tabular} & $\begin{array}{l}600 \\
600\end{array}$ \\
\hline $\begin{array}{r}50 \\
830 \\
150 \\
2000 \\
1250 \\
3000 \\
2800 \\
2400 \\
20\end{array}$ & $\begin{array}{r}850 \\
1000 \\
2300 \\
2300 \\
4700 \\
4700 \\
5960 \\
7200 \\
12600 \\
\end{array}$ & $\begin{array}{l}1 \\
2 \\
3 \\
4 \\
5 \\
6 \\
7 \\
8 \\
9\end{array}$ & $\begin{array}{l}\text { Myeloid } \\
\rightarrow \text { acute }\end{array}$ & $\begin{array}{r}1 \\
2 \\
3 \\
4 \\
5 \\
6 \\
7 \\
8 \\
9 \\
10\end{array}$ & $\begin{array}{r}765 \\
765 \\
850 \\
1140 \\
1260 \\
1950 \\
2000 \\
2000 \\
2350 \\
2350 \\
\end{array}$ & $\begin{array}{r}100 \\
3000 \\
50 \\
150 \\
150 \\
300 \\
143 \\
2000 \\
300 \\
2000\end{array}$ \\
\hline $\begin{array}{r}5180 \\
450 \\
3000 \\
3000 \\
1500 \\
750 \\
142 \\
300 \\
750 \\
3480\end{array}$ & $\begin{array}{r}2440 \\
3000 \\
3000 \\
3050 \\
3300 \\
4000 \\
4270 \\
5000 \\
5000 \\
11680 \\
\end{array}$ & $\begin{array}{r}1 \\
2 \\
3 \\
4 \\
5 \\
6 \\
7 \\
8 \\
9 \\
10\end{array}$ & $\begin{array}{r}\text { Lymphoid } \\
\rightarrow \text { acute acute }- \\
\text { acute } \leftarrow\end{array}$ & $\begin{array}{r}1 \\
2 \\
3 \\
4 \\
5 \\
6 \\
7 \\
8 \\
9 \\
10\end{array}$ & $\begin{array}{l}540 \\
1360 \\
1900 \\
1998 \\
2160 \\
2250 \\
2550 \\
2600 \\
2600 \\
5000 \\
\end{array}$ & $\begin{array}{r}150 \\
150 \\
150 \\
180 \\
180 \\
300 \\
2000 \\
300 \\
2000 \\
450\end{array}$ \\
\hline
\end{tabular}

$\dagger$ The cases recorded here will be described individually and in detail elsewhere.

the period studied, in the whole blood of the patients than in that of the normal individuals, and that the concentration reached higher levels in both groups when the $\mathrm{P}^{32}$ was administered intravenously. This last feature was found to be true in all of the fractions of the blood.

(b) Retention of $P^{32}$ in red blood cells. The same features were found as discussed under $(a)$.

(c) Retention of $P^{32}$ in white blood cells. The concentration of $\mathrm{P}^{32}$ in the white blood cells of the patients was considerably higher than that in the white blood cells of the normal individuals. The metabolic rates of the white blood cells were not determined. The concentration of $\mathrm{P}^{32}$ in the white blood cells of the leukemic patients (particularly the lymphoid cells) was higher following the administration of $\mathrm{P}^{32}$ by the intravenous than by the oral route.

(d) Retention of $P^{32}$ in plasma. The concentration of $\mathrm{P}^{32}$ was higher in the plasma after in- travenous than after oral administration for a short period of time only-approximately 2 to 4 hours. This finding was present in the normal individuals and in the patients.

Figure 2 also shows that there is more retention of radio-phosphorus in blood fractions following intravenous than following oral administration in individual patients receiving $\mathrm{P}^{32}$ by both routes, and that when relatively large amounts of $P^{31}$ accompany the radioactive phosphorus, regardless of route of administration, less of the latter is retained by the fractions. One patient (Case 34) retained about as much $\mathrm{P}^{32}$ in the blood fractions after its oral administration, when accompanied with a small amount of $\mathrm{P}^{31}$, as when the same quantity of radio-phosphorus was administered intravenously in the presence of more than 10 times more $\mathrm{P}^{31}$.

Figure 3 shows that with one exception (R.B.C. of Case 23) the retention of $\mathrm{P}^{32}$ was less in the 


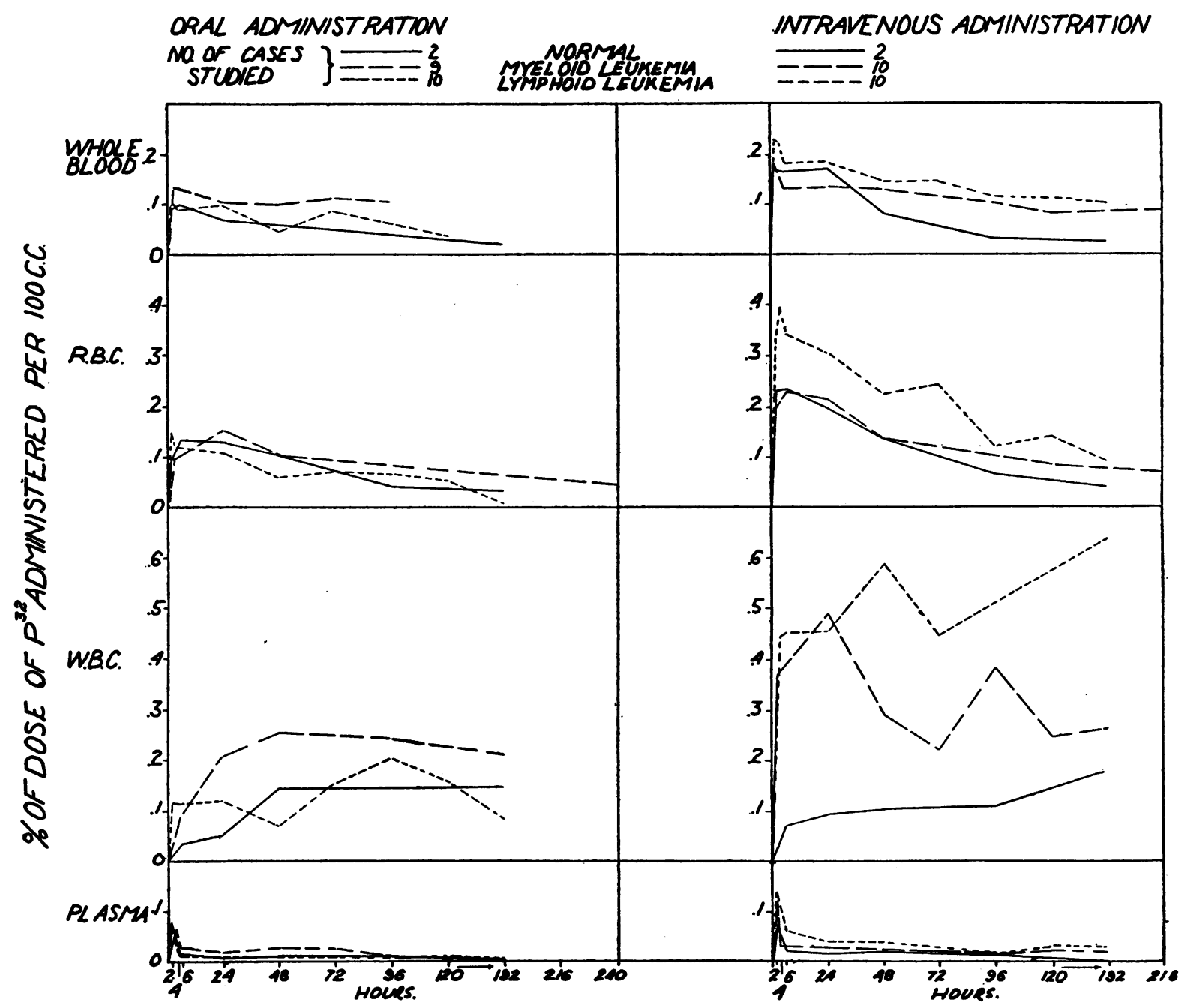

Fig. 1. Average Retention, in Blood Fractions, of P32 Administered Orally and Intravenously in Normal Individuals and in Patients with Leukemia

blood fractions when large amounts of $\mathrm{P}^{81}$ accompanied the $\mathrm{P}^{32}$ than when small amounts of nonradioactive phosphorus were introduced at the same time.

Table II indicates that $\mathrm{P}^{32}$ is retained in the marrow in slightly higher concentrations than corresponding fractions in the peripheral blood at the same time period. The nucleated cells of the marrow include the nucleated red cells.

Table III indicates that the volumes of nuclei and cytoplasm of lymphocytes are about equal, while in myelocytes the nuclei comprise but about $1 / 5$ to $1 / 3$ of the volume of the cell. The ratio of the amounts of $\mathrm{P}^{32}$ retained in the lymphocyte nuclei to the cytoplasm is about 1 to 1 , while in the myelocytes the ratio is 4 to 1 in the cases studied. Constant volumes were obtained by centrifuging samples for exactly 20 minutes at 1450 times gravity.

Table IV indicates that up to 48 hours after administration of $\mathrm{P}^{32}$ the greatest concentration occurs in the acid-soluble fraction of leukemic white blood cells. In 2 patients (Cases 28 and $67)$, it was noted that the concentration of $\mathrm{P}^{32}$ in the phospholipid and nucleoprotein fractions gradually increased following the administration of radio-phosphorus, while that in the acid-soluble fraction decreased. At the end of a period of 96 


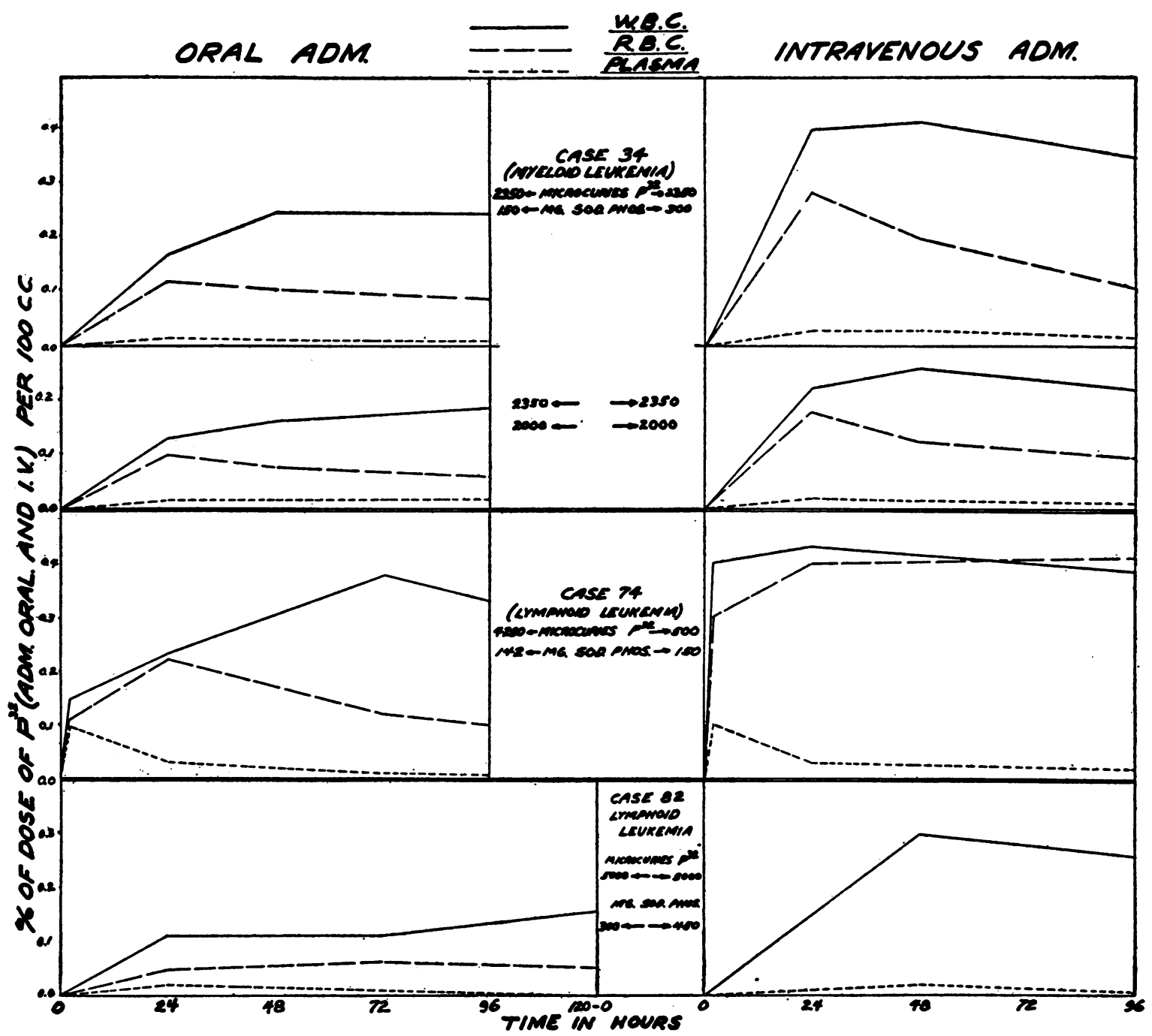

Fig. 2. Variations in Retention, in Blood Fractions, of Paz Administered Intravenously and Orally When Accompanied by Large and Small Amounts of Sodium Phosphate

hours after the administration, the concentration of $\mathrm{P}^{32}$ in the nucleoprotein fraction was equal to or greater than the acid-soluble fraction in 4 of the 5 cases studied.

Figure 4 and Table $\mathrm{V}$ indicate the average per cent of the dose of administered $\mathrm{P}^{32}$ excreted in the urine and feces. When $\mathrm{P}^{32}$ is administered orally, from 15 to 50 per cent is excreted in the urine and feces in both normal individuals and patients during a 4 - to 6-day period. In normal individuals the same percentages are excreted when $\mathrm{P}^{82}$ is administered intravenously, but in the patients from 5 to 25 per cent is excreted. When administered orally, the greater part of the $\mathrm{P}^{32}$ is excreted in the feces; when intravenously, a very small but definite amount is excreted in the feces. Normal individuals excrete large quantities in the urine following intravenous administration. In leukemic patients radio-phosphorus is probably more quickly fixed in the pathological tissues and cells $(3,4)$.

\section{DISCUSSION}

It has been observed $(3,5)$ that leukemic mice and their tissues retain more radio-phosphorus than normal mice and their tissues, that the con- 
LARGE AMOUNTS of sod Aros.
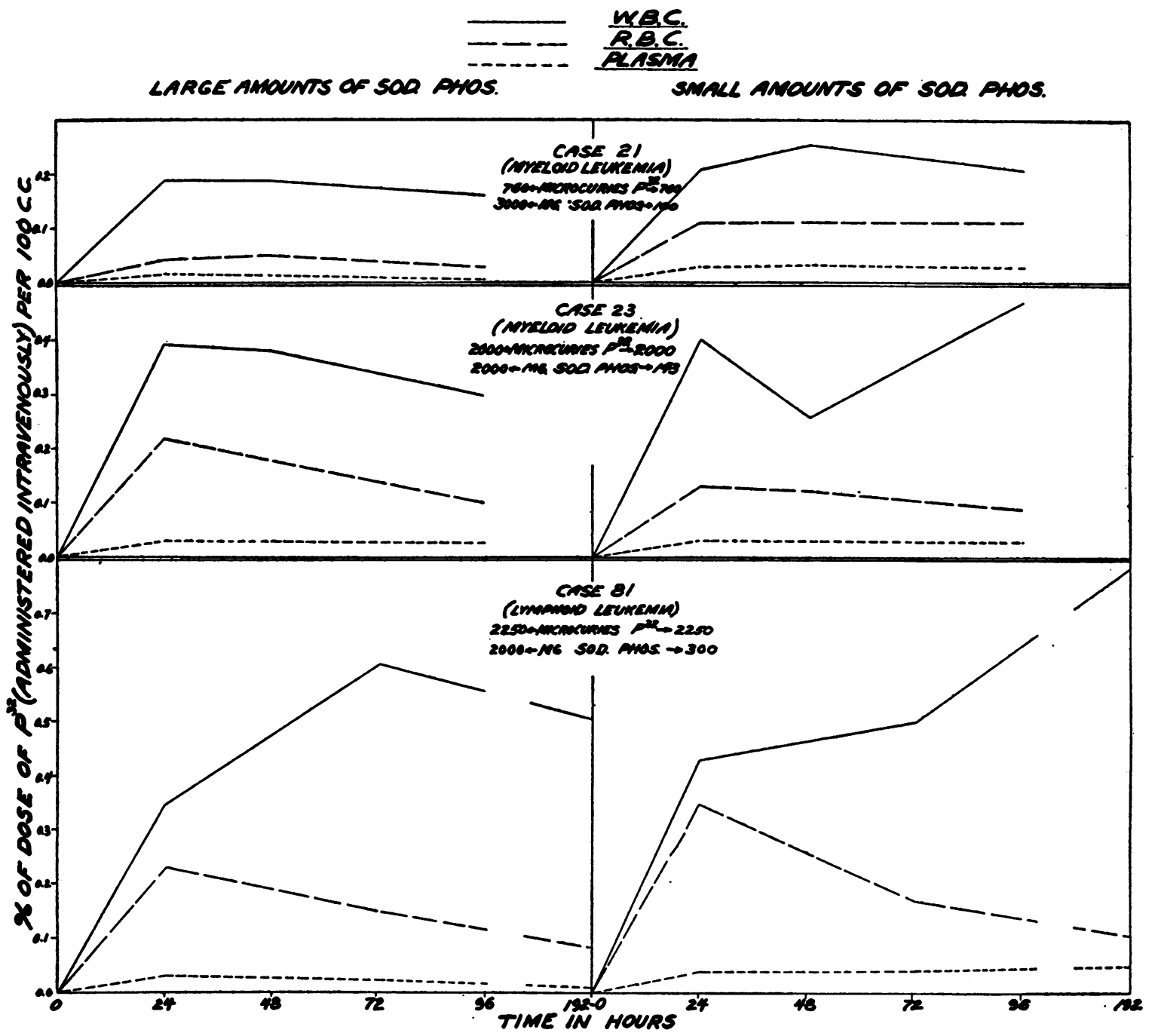

Fig. 3. Variations in Retention, in Blood Fractions, of P32 Administered Intravenously When Accompanied by Large and Small Amounts of Sodium Phosphate

TABLE II

Retention of radio-phosphorus in marrow and peripheral blood of patients with leukemia

\begin{tabular}{|c|c|c|c|c|c|c|c|c|}
\hline $\begin{array}{c}\text { Case } \\
\text { number }\end{array}$ & $\begin{array}{c}\text { Type of } \\
\text { leukemia }\end{array}$ & $\begin{array}{l}\text { Millicuries } \\
\text { of Pas } \\
\text { adminis- } \\
\text { tered }\end{array}$ & $\begin{array}{l}\text { Route of ad- } \\
\text { ministration }\end{array}$ & $\begin{array}{c}\text { Hours } \\
\text { affer } \\
\text { adminis- } \\
\text { tration }\end{array}$ & & $\begin{array}{l}\text { Red blood } \\
\text { cells }\end{array}$ & $\begin{array}{l}\text { Nucleated cells } \\
\text { in marrow. } \\
\text { White blood cells in } \\
\text { peripheral blood }\end{array}$ & Plasma \\
\hline 91 & Lymphoid & 2.16 & Intravenous & 4 & $\begin{array}{l}\text { Marrow: } \\
\text { Peripheral } \\
\text { blood: }\end{array}$ & $\begin{array}{c}\text { Mc. per cc. } \\
0.073 \\
0.063\end{array}$ & $\begin{array}{l}\text { me. per cc. } \\
0.079 \\
0.064\end{array}$ & $\begin{array}{c}\text { uc. per ce. } \\
0.020 \\
0.021\end{array}$ \\
\hline 67 & Lymphoid & 5.0 & Oral & 8 & $\begin{array}{l}\text { Marrow: } \\
\text { Peripheral } \\
\text { blood: }\end{array}$ & $\begin{array}{l}0.056 \\
0.055\end{array}$ & $\begin{array}{l}0.068 \\
0.064\end{array}$ & $\begin{array}{l}0.020 \\
0.010\end{array}$ \\
\hline 28 & Myeloid & 1.95 & Intravenous & 48 & $\begin{array}{l}\text { Marrow: } \\
\text { Peripheral } \\
\text { blood: }\end{array}$ & $\begin{array}{l}0.0260 \\
0.0170\end{array}$ & $\begin{array}{l}0.0925 \\
0.034\end{array}$ & \\
\hline
\end{tabular}


TABLE III

Retention of radio-phosphorus in nuclei and cytoplasm of leukemic white blood cells

\begin{tabular}{|c|c|c|c|c|c|c|c|c|}
\hline Case number & $\begin{array}{c}\text { Type } \\
\text { of } \\
\text { leukemia }\end{array}$ & $\begin{array}{l}\text { Millicuries } \\
\text { of Pss } \\
\text { administered }\end{array}$ & $\begin{array}{l}\text { Route of } \\
\text { adminis- } \\
\text { tration }\end{array}$ & $\begin{array}{l}\text { Days after } \\
\text { adminis- } \\
\text { tration }\end{array}$ & Nuclei & Cytoplasm & Nuclei & Cytoplasm \\
\hline \multirow{3}{*}{61} & \multirow{3}{*}{ Lymphoid } & \multirow{3}{*}{2.0} & \multirow{3}{*}{ Intravenous } & & \multicolumn{2}{|c|}{ volumes per ce. } & \multicolumn{2}{|c|}{ uc. per ce. } \\
\hline & & & & 1 & 0.50 & 0.50 & 0.0970 & 0.121 \\
\hline & & & & 4 & 0.50 & 0.50 & 0.0706 & 0.0763 \\
\hline 77 & Lymphoid & 2.6 & Intravenous & 3 & 0.44 & 0.56 & 0.0708 & 0.0670 \\
\hline 21 & Myeloid & 0.7 & Intravenous & $\begin{array}{l}2 \\
5\end{array}$ & $\begin{array}{l}0.22 \\
0.20\end{array}$ & $\begin{array}{l}0.78 \\
0.80\end{array}$ & $\begin{array}{l}0.0258 \\
0.0297\end{array}$ & $\begin{array}{l}0.0087 \\
0.0078\end{array}$ \\
\hline $21 \mathrm{~A}$ & Myeloid & 0.7 & Intravenous & 8 & 0.32 & 0.68 & 0.0244 & 0.0081 \\
\hline 22 & Myeloid & 3.9 & Oral & 17 & 0.17 & 0.83 & 0.0436 & 0.0127 \\
\hline
\end{tabular}

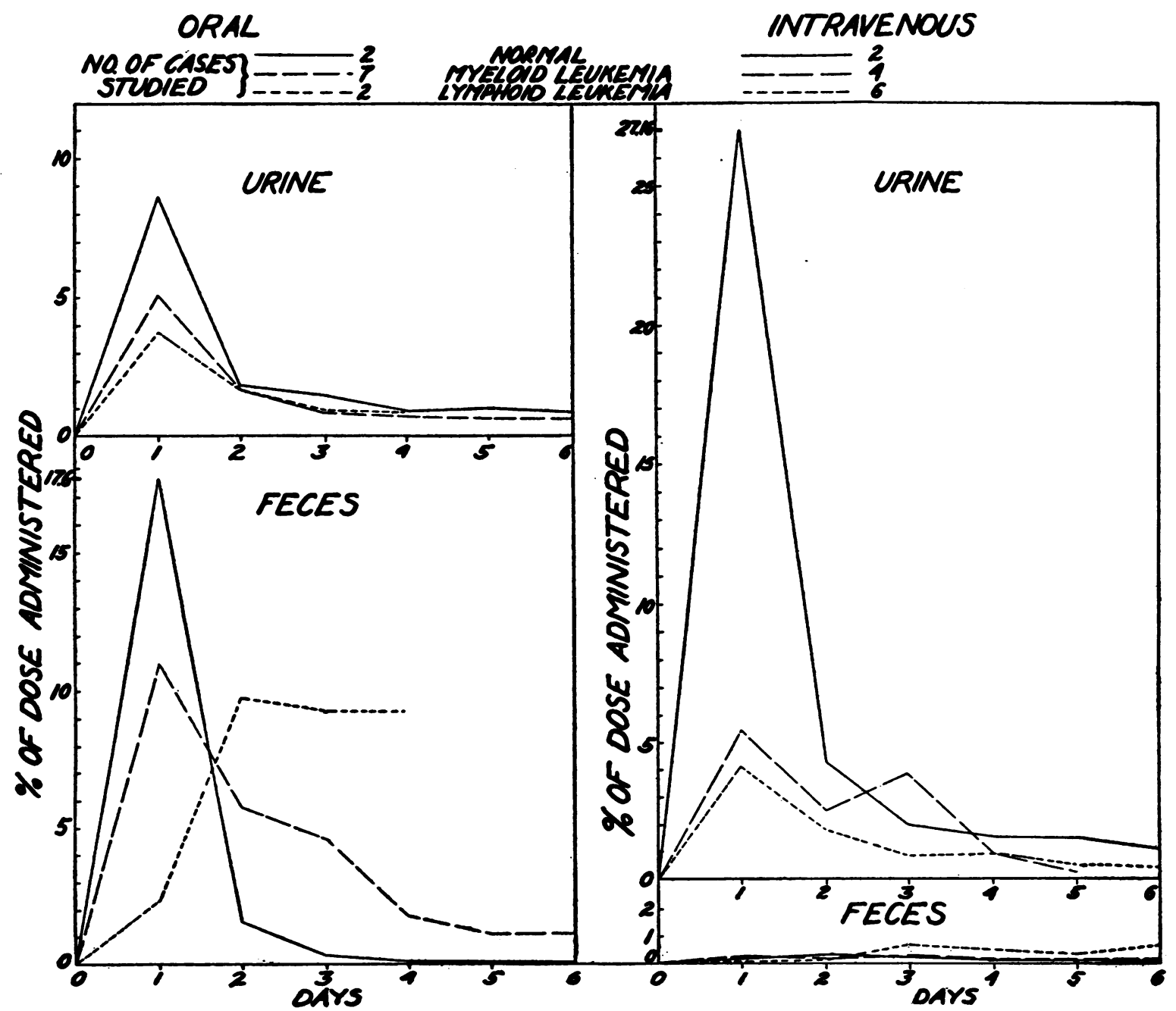

Fig. 4. Average Excretion of $P^{32}$ in Urine and Feces 
TABLE IV

Retention of radio-phosphorus in the phospholipid, acid-soluble and nucleoprotein fractions of leukemic cells

\begin{tabular}{|c|c|c|c|c|c|c|c|}
\hline \multirow{2}{*}{ Case number } & \multirow{2}{*}{ Type of leukemia } & \multirow{2}{*}{$\begin{array}{l}\text { Millicuries } \\
\text { of pas } \\
\text { administered }\end{array}$} & \multirow{2}{*}{$\begin{array}{c}\text { Route } \\
\text { of } \\
\text { administration }\end{array}$} & \multirow{2}{*}{$\begin{array}{l}\text { Hours after } \\
\text { adminis- } \\
\text { tration }\end{array}$} & \multicolumn{3}{|c|}{ Fractionation of white blood cells } \\
\hline & & & & & $\begin{array}{c}\text { Phospho- } \\
\text { lipids }\end{array}$ & $\begin{array}{l}\text { Acid- } \\
\text { soluble }\end{array}$ & $\begin{array}{c}\text { Nucleo- } \\
\text { protein }\end{array}$ \\
\hline & & & & & & Mc. per cc. & \\
\hline 67 & Lymphoid & 5 & Oral & $\begin{array}{l}12 \\
24\end{array}$ & $\begin{array}{l}0.0048 \\
0.0099\end{array}$ & $\begin{array}{l}0.0465 \\
0.0435\end{array}$ & 0.0081 \\
\hline & & & & $\begin{array}{l}24 \\
48\end{array}$ & 0.0162 & 0.0417 & 0.0147 \\
\hline & & & & 96 & 0.0228 & 0.0187 & 0.0393 \\
\hline 61 & Lymphoid & 2 & Intravenous & 96 & 0.0068 & 0.0079 & 0.0248 \\
\hline 28 & Myeloid & 1.95 & Intravenous & 4 & 0.0018 & 0.0195 & 0.0027 \\
\hline & & & & 24 & 0.0039 & 0.0190 & 0.0058 \\
\hline & & & & 48 & 0.0037 & 0.0160 & 0.0077 \\
\hline & & & & 96 & 0.0057 & 0.0117 & 0.0105 \\
\hline 14 & Myeloid & 0.87 & Intravenous & 12 & 0.0055 & 0.0064 & 0.0036 \\
\hline 21 & Myeloid & 0.76 & Intravenous & $\begin{array}{r}120 \\
48\end{array}$ & $\begin{array}{l}0.0018 \\
0.0031\end{array}$ & $\begin{array}{l}0.0010 \\
0.0042\end{array}$ & $\begin{array}{l}0.0018 \\
0.0065\end{array}$ \\
\hline & & & & 120 & 0.0036 & 0.0035 & 0.0059 \\
\hline
\end{tabular}

TABLE V

Average per cent of dese of $P^{*}$ administered orally and intravenously (see below *) which was excreted in the urine and feces of normal individuals and patients with leukemia

\begin{tabular}{|c|c|c|c|c|c|c|c|c|c|c|c|c|c|c|c|}
\hline Days & 1 & 2 & 3 & 4 & 5 & 6 & $\begin{array}{l}\text { Number } \\
\text { of cases } \\
\text { studied* }\end{array}$ & & $\begin{array}{l}\text { Number } \\
\text { of cases } \\
\text { studied* }\end{array}$ & 1 & 2 & 3 & 4 & 5 & 6 \\
\hline & $\begin{array}{l}8.66 \\
5.11 \\
3.86\end{array}$ & $\begin{array}{l}1.83 \\
1.71 \\
1.63\end{array}$ & $\begin{array}{l}1.50 \\
0.909 \\
0.98\end{array}$ & $\begin{array}{l}0.93 \\
0.707 \\
0.87\end{array}$ & \begin{tabular}{|l|l}
1.07 \\
0.634
\end{tabular} & \begin{tabular}{|l|l}
0.83 \\
0.634
\end{tabular} & $\begin{array}{l}2 \\
7 \\
2\end{array}$ & $\begin{array}{l}\text { Urine } \\
\text { Normal } \\
\text { Myeloid } \\
\text { Lymphoid }\end{array}$ & $\begin{array}{l}2 \\
4 \\
6\end{array}$ & $\begin{array}{r}27.16 \\
5.50 \\
4.19\end{array}$ & \begin{tabular}{|l|}
4.26 \\
2.55 \\
1.81
\end{tabular} & $\begin{array}{l}1.99 \\
3.88 \\
0.86\end{array}$ & $\begin{array}{l}1.58 \\
0.97 \\
0.96\end{array}$ & $\begin{array}{l}1.50 \\
0.23 \\
0.56\end{array}$ & $\begin{array}{l}1.11 \\
0.4\end{array}$ \\
\hline & $\begin{array}{r}17.76 \\
11.05 \\
2.33\end{array}$ & $\begin{array}{l}1.55 \\
5.79 \\
9.75\end{array}$ & \begin{tabular}{|l}
0.30 \\
4.64 \\
9.3
\end{tabular} & $\begin{array}{l}0.06 \\
1.746 \\
9.28\end{array}$ & 1.08 & $\begin{array}{l}0.03 \\
1.09\end{array}$ & & $\begin{array}{l}\quad \text { Feces } \\
\text { Normal } \\
\text { Myeloid } \\
\text { Lymphoid }\end{array}$ & & $\begin{array}{l}0.089 \\
0.25 \\
0.022\end{array}$ & $\begin{array}{l}0.35 \\
0.16 \\
0.177\end{array}$ & $\mid \begin{array}{l}0.24 \\
0.27 \\
0.638\end{array}$ & $\mid \begin{array}{l}0.16 \\
0.14 \\
0.484\end{array}$ & $\begin{array}{l}0.02 \\
0.35\end{array}$ & $\begin{array}{l}0.03 \\
0.03 \\
0.68\end{array}$ \\
\hline
\end{tabular}

* Administrations

\begin{tabular}{|c|c|c|c|c|c|c|c|c|}
\hline \multicolumn{4}{|c|}{ Oral } & & \multicolumn{4}{|c|}{ Intravenous } \\
\hline $\begin{array}{l}\text { Mgm. of } \\
\text { NazPOA }\end{array}$ & \multicolumn{2}{|c|}{ Microcuries of Paz } & \multirow{2}{*}{$\begin{array}{c}\text { Cases } \\
\begin{array}{c}1 \\
2\end{array}\end{array}$} & \multirow[b]{2}{*}{ Normal } & \multirow{2}{*}{$\begin{array}{c}\text { Cases } \\
\begin{array}{r}1 \\
2\end{array}\end{array}$} & \multicolumn{2}{|c|}{ Microcuries of Pas } & \multirow{2}{*}{$\begin{array}{c}\text { Mgm. of } \\
\mathrm{Na}_{2} \mathrm{PO}\end{array}$} \\
\hline $\begin{array}{l}600 \\
600\end{array}$ & $\begin{array}{l}1500 \\
1500\end{array}$ & $\begin{array}{c}\text { Average } \\
1500\end{array}$ & & & & $\begin{array}{l}1500 \\
1500\end{array}$ & $\begin{array}{c}\text { Average } \\
1500\end{array}$ & \\
\hline $\begin{array}{r}930 \\
1000 \\
3000 \\
3000 \\
2800 \\
20\end{array}$ & $\begin{array}{r}3850 \\
4000 \\
4700 \\
4700 \\
4700 \\
5960 \\
12600\end{array}$ & 5787 & $\begin{array}{l}1 \\
2 \\
3 \\
4 \\
5 \\
6 \\
7\end{array}$ & Myeloid & $\begin{array}{l}1 \\
2 \\
3 \\
4\end{array}$ & $\begin{array}{r}870 \\
1140 \\
1260 \\
1950\end{array}$ & 1305 & $\begin{array}{l}150 \\
150 \\
150 \\
300\end{array}$ \\
\hline $\begin{array}{l}750 \\
142\end{array}$ & $\begin{array}{l}4000 \\
4270\end{array}$ & 4135 & $\begin{array}{l}1 \\
2\end{array}$ & Lymphoid & $\begin{array}{l}1 \\
2 \\
3 \\
4 \\
5 \\
6\end{array}$ & $\begin{array}{r}540 \\
1360 \\
1900 \\
1998 \\
2160 \\
5000\end{array}$ & 2159 & $\begin{array}{l}150 \\
150 \\
150 \\
180 \\
180 \\
450\end{array}$ \\
\hline
\end{tabular}


centration of radio-phosphorus in the nucleoprotein fraction of leukemic cells of mice increased, while that of the acid-soluble fraction decreased during a 4-day period, that large quantities of non-radioactive phosphorus, when accompanying radio-phosphorus on administration, tend to reduce the amount of $\mathrm{P}^{32}$ retained in the bodies of mice. Similar findings are apparent in humans, as reported in this paper.

The following features were also noted: $(a)$ more radio-phosphorus is retained by patients with leukemia when it is administered intravenously than when given orally; $(b)$ marrow retains radiophosphorus in higher concentrations than blood per unit volume and at the same time period; and (c) relatively greater concentrations of $\mathrm{P}^{\mathbf{3 2}}$ occur in the nuclei than in the cytoplasm of myeloid leukemic cells, while no differences in retention of $\mathrm{P}^{\mathbf{3 2}}$ were noted in the nuclei and cytoplasm of the lymphoid cells studied. From the findings presented above phosphorus apparently passes from the acid-soluble substances of leukemic white blood cells (presumably through enzymatic carrier systems) to substances of nucleoprotein and phospholipid character. The practical point to be emphasized is, that if high concentrations of radiophosphorus are to be obtained in circulating white blood cells, $\mathrm{P}^{32}$ should be introduced intravenously and it should be accompanied by the smallest amount of non-radioactive phosphorus possible. Reducing the phosphorus intake in the diet should also be considered.

\section{SUMMARY}

1. The variations in the retention of administered radio-phosphorus in blood of normal individuals and leukemic patients due to routes of administration and to amounts of accompanying non-radioactive phosphorus are presented.

2. The amounts of radio-phosphorus excreted in the urine and feces, after its administration both orally and intravenously, are given.

\section{BIBLIOGRAPHY}

1. Lawrence, E. O., and Cooksey, D., On the apparatus for the multiple acceleration of light ions to high speeds. Physical Rev., 1936, 50, 1131.

2. Marshak, A., Uptake of radioactive phosphorus by nuclei of liver and tumors. Science, 1940, 92, 460.

3. Tuttle, L. W., Erf, L. A., and Lawrence, J. H., Studies on neoplasms with the aid of radioactive phosphorus. II. The phosphorus metabolism of the nucleoprotein, phospholipid and acid-soluble fractions of normal and leukemic mice. J. Clin. Invest., 1941, 20, 57.

4. Erf, L. A., and Lawrence, J. H., Phosphorus metabolism in neoplastic tissue. Proc. Soc. Exper. Biol. and Med., 1941, 46, 694.

5. Erf, L. A., Tuttle, L. W., and Scott, K. G., Retention of orally administered radio-phosphorus by mice. Proc. Soc. Exper. Biol. and Med., 1940, 45, 652. 